\title{
Model of Rice Farm Insurance to Reduce Losses Due to Harvest Failure
}

\author{
Agung Prabowo, Mustafa Mamat, Sukono
}

\begin{abstract}
The rice farm insurance is one of micro insurance, which is intended for paddy fields. Its use is to reduce or minimize the losses suffered by farmers due to crop failure. In this article various things are related to rice farming insurance and specifically highlight rice farming insurance in Indonesia from the actuarial side. There are several actuarial methods that can be used to determine the amount of rice farming insurance premiums. Calculation of premiums is based on expectations of losses and losses of extreme events. The premium calculation used is: pure premium method, and method of level of coverage. Based on the results of the discussion, it shows that the actuarial fair premium determined in the range of IDR 179,000 to IDR 268,000 . Thus, the official premium of rice farming insurance is IDR 180,000, is the minimum premium for agricultural insurance programs in Indonesia.
\end{abstract}

Index Terms: Rice farming insurance, premiums, actuarial methods, pure premium, level of coverage.

\section{INTRODUCTION}

Agriculture is a business that is full of risks, prone to be affected by climate change which causes flooding, drought and the proliferation of Plant Pest Organisms, all of which end in crop failure. Continual crop failure will weaken the motivation of farmers to survive and continue to work in agricultural business. In the end, it will threaten national food security. Rice farming is a living resource for most families in rural areas of the archipelago. Rice farming is also managed as part of government policy in order to achieve self-sufficiency. This is related to national food security, especially in politics. For this reason, the state must continuously anticipate the risk of a deficit (decrease) in rice production.

Rural and rural communities are the last to be touched by modern innovations and management. Rural communities that are dominated by farmers need to be introduced to a variety of modern breakthroughs to support the growth of a quality rural lifestyle. The attitude of accepting reskin which had been successful in avoiding farmers from the grip of stress due to crop failure or rice production which was not as expected - was not bad. However, an effort needs to be made so that the level or value of losses due to crop failure is

Revised Manuscript Received on April 25, 2019.

Agung Prabowo, Department of Mathematics, Faculty of Mathematics and Natural Sciences, Universitas Jenderal Soedirman, Purwokerto, Indonesia.

Mustafa Mamat, Faculty of Informatics and Computing, Universiti Sultan Zainal Abidin, Kuala Terengganu, Malaysia.

Sukono, Department of Mathematics, Faculty of Mathematics and Natural Sciences, Universitas Padjadjaran, Indonesia. reduced. One of them is by providing agricultural insurance programs for farmers in rural agricultural areas. Most of our people still think that insurance is the umpteenth number in their life priorities, maybe including us. Moreover, the lower middle class, including farmers who are still more focused on meeting their basic needs. Unexpected events such as illness, accident, job loss, crop failure, or death, have a major impact on any household.

The impact of these events will be more severe in low income households. It is very important for every family, including farm families to be able to support themselves and mitigate the risks of these unexpected events. Governments and countries need to contribute to reducing risk due to this unexpected event. For this reason, it is time to develop low-premium insurance products called micro insurance, such as general agricultural insurance, Rice Farming Business Insurance, Cattle Business Insurance and fisherman insurance. Until 2013, the agricultural sector was one of the sectors not yet touched by insurance programs, specifically agricultural insurance, more specifically rice insurance. Actually, in Indonesia agricultural insurance is not new. The implementation of agricultural insurance trials in Indonesia has been carried out since 1982. However, this program is specifically for poor people and farmers, although it is also intended for farmers who own land.

Some studies related to the determination of agricultural insurance include: Woodard et al. [1] discuss the method of loss cost ratio to calculate the amount of agricultural insurance premiums by averaging the cost of loss ratio for each time point for all insurance participants at the regional level. This method assumes that the sum insured and the expectation of compensation are constant over time. In addition to the three methods above, there are other methods that have been used by experts in calculating or determining the amount of insurance premiums. Botts and Bales in Bharamappanavara et al. [2] and Goodwin [3] discuss the normal curve method. This method assumes that the distribution of agricultural crops is normal. Empirical methods, among others, are discussed by Goodwin [4] and Hatt et al. [5]. This method is based on the relationship between the average empirical loss and the amount of the sum insured.

Babcock et al. [6] discuss the calculation of premiums involving opportunities. While Ozaki et al. [7, 8, 9] used parametric and non-parametric methods in calculating agricultural insurance premiums. In the parametric method, 
the assumption is that agricultural crops follow certain distributions such as normal, beta or gamma. Whereas in non-parametric methods histograms and kernel estimators are used to estimate the distribution of agricultural crops. The use of the Bayes method in calculating insurance premiums can be found in Ozaki [7, 8], Ozaki and [9], and Ramadan [10]. Chakrabarti (2014) discusses the technical premium method for calculating agricultural insurance premiums by involving costs or loading factors (cost) $\theta$.

Based on the explanation above, this paper intends to discuss rice farming insurance in Indonesia from the actuarial side, related to various actuarial methods that can be used to determine the amount of premiums in rice insurance. Methods for calculating rice farming insurance premiums (called Rice Farming Business Insurance). Its use is to reduce or minimize the losses suffered by farmers due to crop failure.

\section{MATHEMATICAL MODELS}

\section{A. Distribution of Rice Production}

Estimates of rice yields can be used to determine the amount of premiums that need to be paid. There are at least three methods that can be used, namely (1) parametric methods, (2) non-parametric methods, and (3) semi-parametric methods. The first two methods are the methods most often used in determining the amount of premiums [11, 12, 13].

The parametric method assumes that the distribution function is known and the parameters in the function are unknown, the value will be estimated. Non-parametric methods do not require knowing the distribution function so there is no need for parameter estimation and assumptions required in parametric methods are not needed (may be violated). In addition, the methods used in parametric such as the ML (maximum likelihood) method also do not exist. Non-parametric methods can often help in finding simple parametric models. Non-parametric methods will be selected if the distribution function cannot be assumed with a high degree of certainty. In the semi-parametric method a mixture of two equal distributions is used [14].

One type of distribution that is often used in parametric methods is normal distribution. This is caused by its nature that is simple or easy to apply. Just and Weninger [11] concluded that yields follow a strongly normal distribution. In addition to the normal distribution, the form of distribution for yields is Weibull distribution which has a wide range of skewness.

The function of opportunity density for normal distribution is as follows:

$$
f\left(x \mid \mu, \sigma^{2}\right)=\frac{1}{\sqrt{2 \pi \sigma^{2}}} e^{-\frac{1}{2 \sigma}(x-\mu)^{2}}
$$

In a normal distribution, there are two parameters that are unknown and can be estimated by the ML method. If the variable is random $X \sim N\left(\mu, \sigma^{2}\right)$ with data $x_{1}, x_{2}, \ldots, x_{n}$, then the mean parameter $\mu$ and variance $\sigma^{2}$. can be estimated by the ML method and the result is:

$$
\hat{\mu}=\frac{1}{n} \sum_{i=1}^{n} x_{i} \text { and } \hat{\sigma}^{2}=\frac{1}{n} \sum_{i=1}^{n}\left(x_{i}-\hat{\mu}\right)^{2}
$$

The Weibull distribution is a general version of an exponential distribution with a probability density function:

$$
f(x \mid \gamma, \alpha, \beta)=\frac{\beta(x-\gamma)^{\beta-1}}{\alpha^{\beta}} e^{-\left(\frac{x-\gamma}{\alpha}\right)^{\beta}}
$$

where $x \geq \gamma, \alpha, \beta>0$. Third parameter $\gamma, \alpha, \beta$ successively called location parameters, scale and shape. If location parameters are taken $\gamma=0$ Weibull distribution is obtained with two parameters $\alpha, \beta$. In this distribution, value $x \geq 0$ meaning that rice yield data is positive or zero. This is different from the normal distribution whose results can be negative [15].

In this distribution, value $X \sim W(\alpha, \beta)$ then the Weibull distribution probability density function with two parameters is:

$$
f(x \mid \alpha, \beta)=\frac{\beta(x)^{\beta-1}}{\alpha^{\beta}} e^{-\left(\frac{x}{\alpha}\right)^{\beta}}
$$

Both parameters in the distribution can be estimated by the maximum likelihood method, obtained:

$$
\hat{\alpha}=\left(\frac{\hat{\beta}}{n} \sum_{i=1}^{n} x_{i}\right)^{\frac{1}{\hat{\beta}}}
$$

Estimates for $\hat{\beta}$ cannot be obtained analytically by the maximum likelihood method. Estimates for $\hat{\beta}$ can be obtained by Newton-Raphson iteration method:

$$
\hat{\beta}_{t+1}=\hat{\beta}_{t}-\frac{S_{\beta}\left(\hat{\alpha}\left(\hat{\beta}_{t}\right), \hat{\beta}_{t}\right)}{S_{\beta}^{\prime}\left(\hat{\alpha}\left(\hat{\beta}_{t}\right), \hat{\beta}_{t}\right)}
$$

where $S_{\beta}^{\prime}\left(\hat{\alpha}\left(\hat{\beta}_{t}\right), \hat{\beta}_{t}\right)$ is the first derivative of $\beta$ from function:

$$
S_{\beta}(\hat{\alpha}, \hat{\beta})=\frac{\partial}{\partial \beta} l(\alpha, \beta \mid x)=\frac{n}{\beta}+\sum_{i=1}^{n} x_{i}-n \log \alpha
$$

Iteration will be stopped if $\left|S_{\beta}\left(\hat{\alpha}\left(\hat{\beta}_{t}\right), \hat{\beta}\right)\right|<\varepsilon$ with $\varepsilon$ positive numbers that are quite small. Other methods to get estimates $\hat{\beta}$ is a simple iteration procedure (SIP) method used by Qiao and Tsokos [16] and Ker [19, 20].

\section{B. Determination of Premium}

Insurance companies, both government and private, have the ability to assess the amount of losses experienced 
by farmers, among others, due to seasonal changes. One of them is determining the amount of premium (premium rate). Actuarially, the fair premium is the premium rate that makes insurance contracts do not generate profits (premium equal expected indemnity),

which is not too large so that farmers are able to pay it and not too small so that insurance companies can still exist in managing agricultural insurance. Determining the amount of premium that is actuarially fair for agricultural insurance can be done by estimating the amount of rice production $[17,18$, 21].

Determination of agricultural insurance premiums other than depending on historical losses also depends on volatility and management costs. The planting period is one factor that must be considered. Errors in the selection of planting periods will lead to greater opportunities for crop failure.

\section{Technical Premium}

One technique in determining premiums (technical premium) is to consider the following two things, (1) expected losses, and (2) the risks of extreme events (catastrophe), obtained:

Technical Premium $=\mathrm{AEL}+\alpha[\mathrm{PML}-\mathrm{AEL}]$

where AEL: Adjusted Expected Loss; PML: Maximum Likely Payout in 25 to 100 contract life times; and $\alpha$ : (commission fee + margin + other costs), in the form of a percentage $[22,23,24]$.

\section{Pure Premium}

Chakrabarti [17] discusses the technical premium method for calculating agricultural insurance premiums by involving costs or loading factors (cost) $\theta$. Many methods can be used to calculate the premium amount. For example, with reference to Mircea et al. in Sidi [25] the value of premium expectations $H[X]$, can be done using equations:

$$
H[X]=(1+\theta) \cdot E[X] \quad \theta>0
$$

The parametric method assumes that the crop follows a certain distribution such as normal, beta or gamma. The opportunity for crop losses is the area under the opportunity density function curve, when the yield is smaller than the guaranteed yield [31].

\section{Fair Premium Rate}

The premium level that is actuarially fair is the premium rate at the time the expected compensation equals the premium. The amount of premium in the form of rate is given by Goodwin and Ker [4] in Ozaki et al. [9]:

$$
\text { Premium rate }=\frac{F_{Y}\left(\lambda y^{e}\right) \cdot E_{Y}\left[\lambda y^{e}-\left(Y \mid y<\lambda y^{e}\right)\right]}{\lambda y^{e}}
$$

where $F_{Y}\left(\lambda y^{e}\right)=P\left(Y<\lambda y^{e}\right), E$ state the expectation operator and $F$ is a cumulative distribution function. Furthermore, $\lambda$ states the level of coverage with $0<\lambda<1$ and $y^{e}$ express expectations of the harvest. Chance of loss
$P\left(Y<\lambda y^{e}\right)$ calculated through the area (area) under the probability density function using the trapezoidal rule in estimating it numerically [26, 27].

\section{RESULTS AND DISCUSSION}

\section{A. Implementation of Rice Agricultural Insurance in Indonesia}

Trial implementation of agricultural insurance has been carried out during the planting season of October 2012 to March 2013, in three provinces namely West Java, East Java and South Sumatra. The trials were carried out on each 1000 hectares of rice fields involving P.T. Jasindo Insurance as the executor of insurance. Until now, P.T. Jasindo Insurance is still the implementer of an agricultural insurance program called Rice Farm Business Insurance.

The agricultural insurance program is a mandate of the law that must be carried out by the government and also as a form of concern and partisanship of the government in weak economic communities. Agricultural insurance programs are mandated in articles 37-39, Law No. 19 of 2013 concerning the Protection and Empowerment of Farmers. This program is run by the Ministry of Agriculture. One of the reasons for the need for agricultural insurance is the results of the 2013 Agriculture Census conducted by the Central Bureau of Statistics, about $79.8 \%$ of households with food crops are households that manage rice crops.

Agricultural insurance is made to provide protection to Indonesian farmers against crop failure. Some important things related to the rice farming insurance scheme are:

1) Each participant of maximum agricultural insurance can only drain his 2 hectares of rice fields.

2) Value (money) for coverage or benefits that can be received is IDR 6,000,000 per hectare.

3) Agricultural insurance insurance premiums are set at $3 \%$ of the value of responsibility or IDR 180,000 per hectare, with $80 \%$ subsidized / paid by the government (IDR 144,000 per hectare) and the remaining $20 \%$ paid by farmers (IDR 36,000 per hectare). Thus, farmers only pay a premium of $0.6 \%$ of the sum assured.

4) The types of risks that can be insured are drought, flooding, and attack by Plant Pest Organisms.

5) The insurance period is valid for one planting season.

6) Farmers who only harvest a maximum of $25 \%$ of the planted area will receive full compensation (IDR $6,000,000)$. For other cases, depending on the level of damage and age of planting [28, 29, 30].

As a form of partnership with farmers, this agricultural insurance program is run with a premium of IDR 144,000 per hectare borne by the government and IDR 36,000 per hectare paid by farmers [30]. Thus, from the total premium of IDR 180,000 per hectare, farmers only pay $20 \%$, while the remaining $80 \%$ is subsidized by the government. The types of risks insured are crop failures due to floods, droughts and pests or so-called Plant Pest Organisms.

In the trial, a wide range of paddy fields that can be carried out P.T. Jasindo's Insurance is 623.12 hectares, 
still far from the expectations of 3000 hectares for three provinces. With a premium of IDR 180,000 per hectare, the total premium received by P.T. Jasindo Insurance should be IDR 112,161,600. Assuming that all claims filed demand maximum compensation (IDR 6,000,000), the company can only pay 18 claims. So, from the premium received, P.T. Jasindo Insurance will suffer losses because in the field implementation it is impossible for only 18 claims to occur or only crop failures on an area of 18 hectares.

In fact, crop failure occurred on a land area of 87.28 hectares. That is, P.T. Jasindo Insurance must pay a claim of 87.28 x IDR 6,000,000 = IDR 523,680,000. As such, claims paid to farmers by P.T. Jasindo Insurance is $467 \%$ of the value of the premium received. It is clear, in this trial P.T. Jasindo Insurance suffered a loss of IDR 523,680,000 - IDR $112,161,000=$ IDR 411,519,000.

As a comparison of the results of the above calculations, by taking the experience of managing rice in the Gombong Subdistrict, Kebumen Regency, for one hectare of planting area farmers can harvest as much as 20 quintals (already reduced by the amount of $\mathrm{kg}$ of rice for harvesters). By assuming the price of grain per $\mathrm{kg}$ is IDR 4,500, then the farmer's income per hectare in one planting period is $2,000 \mathrm{x}$ IDR 4,500= IDR 9,000. This happens when the harvest runs normally. Revenues of IDR 9,000,000 are farmers' income (not profits) for per hectare of planting area in one planting period. The advantage gained by farmers is the amount of income of IDR 9,000 minus all costs incurred during the rice planting process.

Estimated the net profit of farmers for each hectare is one third or equal to IDR 3,000,000. This means that the cost of planting rice is two-thirds of the income of one planting season. The cost of planting rice is increasingly becoming more expensive which has an impact on the smaller net profits that can be enjoyed by sharecroppers. However, this figure shows that tenant farmers can only survive. Net profit of IDR 3,000,000 is the result of planting for 3 months. That is, the average farmer's profit per month is IDR $1,000,000$ or IDR 33,000 per day. If all agricultural work is managed by all family members, without involving labor, then the net profit will exceed the IDR 3,000,000 number.

Associated with agricultural insurance, crop failure occurs if farmers can harvest a maximum of $25 \%$ of the planting area. If the crop fails, the farmer will get IDR $6,000,000$ (from insurance benefits) plus (500 kg x IDR $4,500)=$ IDR 8,250,000. Beautiful numbers. Thus, agricultural insurance can reduce or minimize losses experienced by farmers with a loss rate of around IDR 750,000 to a maximum of IDR 3,000,000. This means that if the farmer experiences a $100 \%$ crop failure, then all insurance benefits are used up for planting costs, so there is no slight profit in the planting period.

Thus, agricultural insurance is designed only to replace the planting costs incurred during one planting season so that if the crop fails $100 \%$, the farmers will not profit and not lose. Actually, farmers will lose as much as the premium paid is

IDR 36,000 (however agricultural insurance does not make the farmers prosperous). If the level of damage is $75 \%$ or can still harvest $25 \%$ of the planting area, then the farmers still get a profit of IDR 750,000 (minus IDR 36,000 premium). These calculations explain why the maximum chosen agricultural insurance benefit is IDR 6,000,000. Other calculations for damage rates of less than $75 \%$ and damage depending on the age of planting.

With IDR 180,000 premium (IDR 144,000 premium subsidy plus IDR 36,000 self-paid premium) and IDR 6,000,000 compensation (sum assured), 34 farmers need to be participants in agricultural insurance. Of the 34 agricultural insurance participants, a premium of $34 \mathrm{x}$ IDR $180,000=$ IDR 6,120,000 will be collected with a difference of IDR 120,000 for the sum insured. That is, from 34 participants there can only be one farmer who fails to harvest, or the chance of crop failure is $1 / 34=0.02941=0.03$. An analogous calculation gives a number of 100 agricultural insurance participants, there can only be 3 farmers failing crops or the chance of crop failure is 3 hectares from every 100 hectares. It's break even. The company is not profitable and does not lose. The numbers of agricultural insurance participants as many as 34 which have exceeded 30 are required in the law of large numbers, and in the calculation of premiums can be approached with a normal distribution.

The latest data [29] states that in the last two years, the area of insured farmers' fields has increased. In 2015-2016 the area of new insured land was 660,000 hectares, but it is expected to increase to 1 million hectares by the end of 2017. Growing farmers' awareness of the threat of crop failure due to rat pests, plant hopper and other plants diseases, as well as the threat of flooding and drought are reasons the increase in the area of rice fields that are assumed.

Even though the premium is quite small (IDR 36,000) compared to the compensation that will be received (a maximum of IDR $6,000,000$ ) or around $0.6 \%$ of the sum insured, the farmer who survives as an agricultural insurance participant in the next planting period is the farmer who has felt the benefits of this insurance . Farmers who have taken part in agricultural insurance, but the harvest is normal so that they do not receive payment of insurance money from this insurance program, in the next planting period they are reluctant to return to participate in participating in agricultural insurance. Another fact is that $75 \%$ of agricultural insurance participants are sharecroppers, not landowners.

\section{B. Basic Model of Premium Calculation}

The following is the determination of the amount of premium made by Mutaqin, Kudus and Karyana [14]. Suppose $X$ the random variable states the average rice yield per hectare from a farmer, with the opportunity density function $g(x)$ and expectations $E[X]$. In an agricultural insurance program, farmers who only harvest a maximum of $25 \%$ of the planting area will receive a full compensation of IDR 6,000,000. That is, if $X<0.25 \cdot E[X]$ then the farmer will receive a compensation of IDR $6,000,000$ and the farmer will not receive compensation, benefits, benefits or reimbursement of IDR 0 from the insurance company if the 
entire planting area can be harvested. Meanwhile, if the area of land that can be harvested is in the range $0.25 \cdot E[X]<E[X]$ then the amount of replacement is varied and calculated by formula:

$$
\frac{8}{E[X]}(E[X]-X)
$$

The explanation above is a formulation of compensation for agricultural insurance programs with compensation (replacement money) can be stated with random variables $I$ that is a random variable which states the amount of compensation (in million rupiah), as follows:

$$
I= \begin{cases}0 & ; X \geq E[X] \\ \frac{8}{E[X]}(E[X]-X) & ; 0.25 \cdot E[X]<X<E[X] \\ 6 & ; X \leq 0.25 \cdot E[X]\end{cases}
$$

The expected value is

$$
\begin{aligned}
E[I]= & E[6] \cdot P(X \leq 0.25 \cdot E[X]) \\
& +E\left[\frac{8}{E[X]}(E[X]-X)(0.25 \cdot E[X]<X<E[X]]\right.
\end{aligned}
$$

$$
P(0.25 \cdot E[X]<X<E[X])
$$

Of course it must be assumed that random variables are normally normal distributions. Mutaqin, Kudus and Karyana [14] gave the formula for large agricultural insurance premiums that were actuarially fair for this case, namely:

$$
E[I]=6 \cdot \Phi\left(\frac{-0.75 \mu}{\sigma}\right)-8 \frac{\sigma}{\mu}\left[\phi\left(\frac{-0.75 \mu}{\sigma}\right)-\frac{1}{\sqrt{2 \pi}}\right]
$$

The estimated premium is calculated using the standard deviation of the sample, that is, because of the estimated population variance, i.e. $\sigma^{2}$ is not biased, so that:

$$
E[I]=6 \cdot \Phi\left(\frac{-0.75 \cdot \bar{x}}{s}\right)-8 \frac{s}{\bar{x}}\left[\phi\left(\frac{-0.75 \bar{x}}{s}\right)-\frac{1}{\sqrt{2 \pi}}\right]
$$

Application of this case by using rice productivity data in 14 districts in West Java. Not all districts have productivity with normal distribution so that premiums cannot be settled, for example Bandung, Tasikmalaya, Ciamis, Sumedang and Karawang (6 of 14). While for Sukabumi, Cianjur, Cirebon, Majalengka, Indramayu, Subang, Purwakarta and Bekasi districts, it can be proven that their productivity is normally distributed. With the premium formula can be determined actuarial fair premium in the range of IDR 179,000 to IDR 268,000. The lowest premium in Majalengka Regency and the highest in Purwakarta Regency. Thus, the official premium of rice farming insurance of IDR 180,000 is the minimum premium for agricultural insurance programs in Indonesia.

\section{CONCLUSION}

In this article various things related to rice farming insurance have been described and specifically highlight rice farming insurance in Indonesia from the actuarial side. The above description explains the role of actuarial science, especially regarding the risk guarantee of residents / residents of cities / regions against floods, droughts and pest disturbances in rice production. The problems reviewed by Mutaqin, Kudus and Karyana (2016) have not determined the percentage of premium sharing between the government and farmers, which in the implementation of rice farming insurance premiums of $80 \%$ is paid by the government. The model also has not included the damage element of rice planting which depends on the age of planting. Furthermore, in the trial of rice farming insurance it turns out that all claims that occur are maximum claims. There are no partial claims with payment of compensation under the maximal compensation of IDR 6,000,000. This impacts the differences in results in mathematical modeling. Fuzzy use is also possible in calculating rice farming insurance premiums.

\section{REFERENCES}

1. J. D Woodard,. B. J Sherrick, and G.D. Schnitkey. "Actuarial impact of loss cost ratio ratemaking in U.S. Crop Insurance Programs." Journal of Agricultural and Resource Economics, vol. 36, no. 1, pp. 211-228, 2011.

2. S. C. Bharamappanavara, M. S. Hasanabadi, J. A. Handigol, R. A. Yeledalli. "Alternative model for crop insurance: A case of onion crop (allium cepa)." Proceedings of the International Conference on Applied Economics - ICOAE, pp. 85-90, 2010.

3. B. K. Goodwin. "An empirical analysis on the demand for multiple peril crop insurance: Reply." American Journal of Agricultural Economics, vol. 76, pp. 952-953, 1994.

4. B. K. Goodwin and A.P Ker. "Nonparametric estimation of crop yield distribution: Implication for rating group-risk insurance contract." American Journal of Agricultural Economics, vol. 80, no. 1, pp. 139-153, 1998.

5. M. Hatt, E. Heyhoe, and L. Whittle. Options for Insuring Australian Agricultural. Department of Agriculural, Fisheries and Forestry, Australian Bureau of Agricultural and Resources Economics and Sciences (ABARES), 2012.

6. S. Brahim-Belhouri and A. Bermak. "Gaussian process for nonstationary time series prediction." Computational Statistics \& Data Analysis, vol. 47, no. 4, pp.705-712, 2004.

7. V. A. Ozaki. "Pricing farm-level agricultural insurance: A bayesian approach.” Empirical Economics, vol. 36, pp. 231-242, 2009.

8. V. A., Ozaki and R. S. Silva. "Bayesian ratemaking procedure of crop insurance contracts with skewed distributions." Journal of Applied Statistics, vol. 36, no.4, pp. 443-452, 2009.

9. V. A. Ozaki, B. K. Goodwin, and R. Shirota. "Parametric and nonparametric statistical modelling of crop yield: implication for pricing crop insurance contracts." Applied Economics, vol. 48, pp. 1151-1164, 2008.

10. A. Ramadan. "Empirical bayes nonparametric density estimation of crop yield densities: Rating crop insurnace contract." Thesis Program Master pada The Faculty of Graduate Studies of The University of Guelph, 2011.

11. R. E. Just and Q. Weninger. "Are crop yields normally distributed ?" American Journal of Agricultural Economics, vol. 81, no. 2, pp. 287-304, 1999.

12. R. E. Just, L. Calvin, and J. Quiggin. "Adverse selection in crop insurance: Actuarial and Asymmetric Information Incentives." American Journal of Agricultural Economics, vol. 81, pp. 843-849, 1999.

13. Y. Long. Empirical studies of corn yield distribution modeling. Paper, Presented to the University of Waterloo in partial fulfillment of the requirement for thr degree of Master of Mathematics in Computational Mathematics, 2015.

14. A.K. Mutating, A. Kudus, and Y. Karyana. "Metode parametrik untuk menghitung premi program asuransi usaha tani padi di Indonesia." Ethos Jurnal Penelitian dan Pengabdian Masyarakat, 2016, 318-326.

15. C. H. Nelson and P. V. Preckel. The conditional beta distribution as a stochastic production function. American Journal of Agricultural Economics, vol. 71, no. 2, pp. 370-378, 1989.

16. H. Qiao and C. P. Tsokos. "Parameter estimation of the Weibull probability distribution." Mathematics and Computers in Simulation, vol. 37, pp. 47-55, 1994.

17. T. Chakrabarti. Crop insurance: an actuarial perspective, 2014. 
http://www.actuariesindia/org/\%28X\%281\%29S\%28ykvdba4550txwoer sp1tkw55\%29\%29/micb/wci2014/Tania-Chakrabarti.pdf.

18. P. Hazell, C. Pomareda, and A. Valdes. Crop insurance for agricultural development:Issues and experience. London: The John Hopkins Press, 1986.

19. A. P. Ker and K. Coble. "Modeling conditional yiled densities." American Journal of Agricultural Economics, vol. 85, no. 2, pp. 291-304, 2003.

20. A. P. Ker and B. K. Goodwin. "Nonparametric estimation of crop insurance rate revisited." American Journal of Agricultural Economics, vol. 82, no. 2, pp. 463-478, 2000.

21. C. Lanoue, B. J. Sherrick, J. D. Woodard and N. D. Pasulson. Evaluating yield models for crop insurance rating. Paper, Presented at the joint annual meeting of the Agricultural and Applied Economics Assosiation, The Canadian Agricultural Economics Society and the Western Agricultural Economics Association, Colorado, 2010.

22. B. J. Sherrick, F. C. Zanini, G. D. Schnitkey, and S. H. Irwin. "Crop insurance valuation under alternative yield distribution." American Journal of Agricultural Economics, vol. 86, no. 2, pp. 406-419, 2004.

23. V. Tirupattur, R. J. Hauser, and N. M. Chaherli. "Crop yield and price distribution effects on revenue hedging." Finance, no. 9612004, EconWPA, Dec., 1996.

24. C. Zulauf and A.D. Summer. Economics and environmental effects of agricultural effects of agricultural insurance program. The Council of Food Agricultural Aconomics, 2012.

25. P. Sidi, M. B. Mamat, Sukono, and S. Supian. "Evaluation model for risk insurance premiums of building damage caused by flood: Case study in Citarum Watershed, Southern Bandung, Indonesia." Journal of Engineering and Applied Sciences, vol. 12, pp. 4420-4425, 2017.

26. B. A. Babcock, C. E. Hart, and D. J. Hayes. "Actuarial fairness of crop insurance rates with constant rate relativities." American Journal of Agricultural Economics, vol. 86, no. 3, pp. 563-575, 2004.

27. B. M. Sharma. "Role of yield data in national agricultural insurance scheme." Journal of Indian Society of Agricultural Statistics, vol. 54, no. 1, pp. 139-173, 2011.

28. S. M. Pasaribu. "Developing rice farm insurance in Indonesia." Agriculture and Agricultural Science Procedia, vol. 1, pp. 33-41, 2010.

29. Suara Merdeka. Luas Lahan yang Diasuransikan Semakin Bertambah. Senin, 5 Juni 2017.

30. Y. H. Supartoyo and Kasmiati. Asuransi pertanian sebagai alternatif mengatasi risiko usaha tani menuju pertanian berkelanjutan: Tinjauan konseptual. Tersedia: https//www.academia.edu/4766244/ASURANSI Diakses 29 Mei 2017.

31. Sukono, I. Aisah, Y.R.H. Tampubolon, H. Napitupulu, S. Supian, Subiyanto and P. Sidi. "Estimated Value of Insurance Premium Due to Citarum River Flood by Using Bayesian Method." IOP Conference Series: Materials Science and Engineering, vol. 332, pp. 1-11, 2018. 